\title{
An Investigation into Concerns of English Instructors at Turkish Universities
}

\author{
Esra Yatağanbaba \\ Hitit University, Turkey \\ E-mail: esra1987erdogan@gmail.com
}

Received: October 24, 2014 Accepted: November 15, $2014 \quad$ Published: November 21, 2014

doi:10.5296/ijele.v3i1.6655 URL: http://dx.doi.org/10.5296/ijele.v3i1.6655

\begin{abstract}
This study aspires to reflect on future objectives of teacher education in terms of focusing on common professional concerns of English language instructors in complex and challenging teaching environments at tertiary level. In this research, it is aimed to investigate the professional concerns of EFL instructors impacting on their teaching practice. First, a semi-structured questionnaire consisting demographic data of the participants and open ended-questions was delivered to English instructors working in different Turkish universities in order to see what their concerns were and how they were regarded and experienced by these instructors. Then, the answers given to open-ended questions underwent content analysis in order to shed light upon these concerns in a more detailed fashion. In the end, the concern levels in 11 broad areas (methodology, content, technology, classroom issues, learner-related issues, administrative issues, job satisfaction, testing and classroom environment), the factors impacting on teacher these concerns besides the relationship between gender and teaching experience regarding professional concerns were addressed. Limitations and suggestions were offered for further studies to highlight the instructors' concerns at the end of the study.
\end{abstract}

Keywords: Teacher education, Teacher beliefs, Teacher concerns, English instructors, EFL 


\section{Introduction}

Defined as "an uneasy state of mind usually over the possibility of an anticipated misfortune or trouble" by Merriam-Webster Online Dictionary, concern is simply put an anxiety or worry about an issue. Besides a mind's being at unease, concern could be described as a cause for apprehension as well. Bearing teaching is a stressful and demanding job in mind, it should not be wrong to state that teachers including language teachers at different contexts, under different conditions and with ever changing roles are required to pursue a growth and development for their own professional accountability.

Teachers' concerns about their professional practices have been quite a popular issue for more than 40 years (Freeman, 1989; Fuller, 1969; Veenman, 1984; Reeves \& Kazelskis, 1985; Kleinsaser, 2013; Pigge \& Marso, 1997 et al.). Mainly growing out of Fuller's seminal work Concerns of Teachers (1969), teachers'/instructors' professional concerns vary greatly from classroom management to job satisfaction.

The professional concerns of EFL instructors and especially studies concerning beliefs and self-efficacies of them have grown in importance in the light of teacher cognition and attitudes in language teaching (Borg, 2003; Boz \& Boz, 2010; Coladarci, 1992; Gaith \& Shaaban, 1999; Zacharias, 2003 et al.) With the aim of uncovering the concerns of EFL instructors at tertiary level and discovering the reasons of these concerns, this study set out to reach as many EFL instructors working at both state and private institutions across Turkey via semi-structured questionnaires. The concern items in the questionnaire were largely derived from the literature especially from Veenman (1984) and Griffiths' (2012) valuable studies. The research questions of the current study were:

1. What are the professional concerns of EFL instructors working at tertiary level?

2. How do gender and teaching experience factors relate to these professional concerns?

\section{Background}

Although teacher and student concerns studies started before Fuller's article Concerns of Teachers (1969), her research set the agenda for further studies (Boz, 2008). Before publishing this phenomenal study, Fuller, Pilgrim and Freeland (1967) suggested a model comprising of six stages (as cited in Conway \& Clark, 2003). The six stages asked the questions given below:

Stage 1: Where do I stand?

Stage 2: How adequate am I?

Stage 3: Why do they do that?

Stage 4: How do they think I am doing?

Stage 5: How are they doing?

Stage 6: Who am I?

As one can see, the questions given above formed the basis of the later studies, especially the stages of concerns. Following this study, after two years a concern model consisting of three stages during a teacher's professional life was presented. These stages are self-concerns, task-related concerns, and impact concerns. In the first stage, the teacher is worried about her 
classroom management skills, disciplines, the opinions of students and parents about her teaching. According to (Boz \& Boz, 2010), these concerns could be linked to their survival concerns. These feelings subside as the teacher becomes more experienced with teaching and managing the order in the classroom, but leaves its place to another stage which is task-related concerns. In this stage, the teacher is concerned about other issues, such unhappiness with curriculum, lack of time and resources for class preparation, grading and planning the lesson, along with administrative issues. In the final stage, the teachers are concerned about their learners; whether they contribute to their intellectual growth, or have any effects on their students' emotional development or not.

Fuller's pioneering study led to design of a framework called CBAM (Concerned Based Adoption Model) and out of this framework a questionnaire called SoC was developed so as to evaluate the affective and behavioural changes in teachers, teacher educators and learners towards innovations and develop professional development programs supporting education innovation (Kwok, 2014).

Developed by Hall et al. (1977), Concerned Based Adoption Model is a theoretical framework to describe, explain and predict the concern levels of teachers, teacher educators and learners (as cited in Kwok, 2014). CBAM comprises of 7 stages (Halloway, 2003):

1. Awareness: describes a teacher being aware but not really interested or concerned with innovation.

2. Informational: interested in some information of change.

3. Personal: wants to know the personal impact of the change.

4. Management: being concerned about how the change will be managed.

5. Consequence: interested in the impact of the change on school and learners.

6. Collaboration: interested in working with colleagues.

7. Refocusing: refining the innovation to improve learning results.

However some studies assert that professional concerns of teachers do not progress in a linear fashion as given in the stages or framework given above; in other words, not all the teachers experience the stages of concerns consecutively, some may have start from the second stage and other might go through all the stages at the same time (Reeves and Kazelskis 1985; Pigge and Marso 1997; Conway, 2001, Watzke, 2007 et al.). Concerns-based studies up-to-date have been cross-sectional and compared the evolvement of student-teachers' concerns at different levels of their training (Poulou, 2007).

In a parallel fashion, Hagger and Malmberg (2011) claimed that later models developed from Fuller's could be divided into two phases: earlier survival stage such as classroom management, planning and organization of content, and a phase dwelling on conceptualized, adaptive and intuitive practices which help promoting students' higher learning.

According to Conway (2003), although there is a sheer number of studies based on teachers' professional concerns, there are mainly two strands derived from Fuller's research: comprehending the dynamics of pre-service and early in-service teacher training, (Poulou, 2007; Woodcock, 2012; Kim \& Cho, 2013; Roofe \&Miller, 2013; et. al.), and adoption of innovation by using CBAM framework (Hord \& Hall, 2000; Liu \&Huang, 2005; Kwok, 2013 
et al.). Research on how teachers at different stages of their career vary has been conducted either by focusing on one stage at a time or comparing teachers at different stages of experiences (Conway \& Clark, 2003; Veenman, 1984 et al.) In accordance with these studies, Watzke (2007) claimed that pre-service teachers expressed moderate levels of concerns related to classroom management and instructional materials, personal growth of students and professional adequacy and acceptance. On the other hand, teachers who had been teaching for a year became highly concerned about their impact on the students, such as learning problems and student academic and emotional growth, besides being highly concerned about their professional growth (as cited in Hagger \& Malmber, 2011). However, it should not be expected to be valid across all contexts since Younger, Brindley, Padder and Hagger (2004) reported that pre-service teachers had so complex thinking about teaching as more experienced teachers.

As to the EFL instructors, there are not many studies which primarily focus on EFL instructors' concerns in the contexts of tertiary level in Turkey. Although there are studies about EFL instructors' burnout, (Cephe, 2010; Özkanal \& Arıkan, 2010 as cited in Öztürk, 2013), perspectives of or attitudes towards professional development (İyidoğan, 2011; Çelik, Çepni, \& İlyas, H., 2012; Hürsen, 2012 et al.).

Griffiths (2012) mentioned that English language teaching has been challenged by many issues like modern technology, the role of English we teach, debates about native vs. non-native teachers, English as a medium of instruction, ESP, EAP, CLIL etc. Yet she drew attention to the teacher herself; what the position of English teacher is in this context; what the complaints of an EFL instructor. In her analysis, she delivered questionnaires to 46 practicing teachers studying master's degree at a private university in Istanbul, Turkey and asked them to rate their professional concerns in six broad areas: methodology, content, technology, English as an International Language (EIL), professional accountability, and classroom issues. She found out that classroom issues were the most concerning area, closely followed by content issues. Teachers were quite anxious about classroom management and discipline issues in their classes. They seemed to be the least anxious regarding methodology and EIL. Women working at tertiary level were more concerned than men in terms of classroom issues. At the end of her study, she pointed at the necessity to conduct these studies in other context with larger populations and more detailed accounts regarding EFL teachers' concerns.

With the current study, it was aimed to fill this gap in literature. It included fewer participants, but new areas were added to the questionnaire and more detailed accounts were collected from the respondents in order to describe them via content analysis besides involving only EFL instructors at tertiary level in the sample.

\section{Method}

This study was carried out with Turkish EFL instructors employed at both state and private universities in Turkey by using a questionnaire consisting of demographic information of the participants, scales from 1-4 (1-extremely concerned, 2-very concerned, 3-somwhat concerned, 4-very concerned) regarding their concerns about items given, such as 
methodology, content, collegial support etc. and open-ended questions related to these concerns.

\subsection{Participants}

41 EFL instructors working at tertiary level across Turkey took part in this study. The participants were reached face-to-face or via email by using personal email addresses or a social network site (Facebook). A total of 41 instructors, female $(\mathrm{N}=30)$ and male $(\mathrm{N}=11)$ returned the questionnaires. Since there was a high difference between male and teacher dominance in this study, the researcher regarded this issue as a limitation for the study. Age of the participants, their academic qualifications and teaching experiences in terms of year were other independent variables in the current study.

\subsection{Research Design}

Both quantitative and qualitative research designs were adopted in this study. The aims of this research were collecting demographic data and concern levels of participants for the given items in the questionnaire statistically first, and then interpreting statistical information given in the questionnaires. Finally, content analysis was applied to elaborate the main reasons of the participants for their academic concerns.

\subsection{Instruments}

Vastly used a data collection instrument in quantitative and qualitative designs, a questionnaire which was prepared by the researcher herself was administered. The questionnaire was designed as semi-structured; Section A dealt with the personal details of the participants and Section B listed some items and each item listed on a 4 Likert scale $(1=$ Extremely concerned $2=$ Very concerned $3=$ Somewhat concerned $4=$ Not concerned at all). For each item, there were open-ended questions regarding the reasons of those academic concerns. Content analysis and SPSS 17.0 were used to interpret the data.

\subsection{Procedure}

For the credibility and sensitivity issues, steps given in the book Research Methods in Education were followed (Cohen, Manion \& Morrison, 2007, p. 318). Participants were informed about the content of the questionnaire and their consent was taken before delivering it. They were reminded that they could withdraw from the study whenever they liked besides there was a potential that this research could help them realize what bothers them the most in their teaching experience.

Bearing the importance of validity, reliability and practicability of the questionnaire, a pilot was administered before delivering the questionnaires to the participants (Cohen, Manion \& Morrison, 2007, p. 341). The draft version was sent to five participants and their feedback was asked about wording, ambiguities if there were any, items, clarity of instructions, layout and any other suggestions to be included in the questionnaire.

After reformatting the layout and wording of the questionnaire, a reliability test was administered in order to eliminate the items which were not reliable and valid. The Cronbach's Alpha of the 11 concern items was found 0.82 which made the questionnaire reliable to use it for further analysis. 
Once analyzing the statistical values of the responses, the open-ended questions which were regarded the backbone of the study since it was aimed to determine major problems of EFL instructors were investigated via content analysis. Research question to address for open -ended questions and population of sample were defined; the question was what the main concerns of EFL instructors were in given items and sample made up the questionnaires on which comments were added to the concern items. Then comments on these items were divided into units of analysis. Third, the analysis was carried on word and phrase basis, namely, syntactic sampling unit (Cohen, Manion \& Morrison, 2007, p. 478).

Each item was coded and some codes subsumed each other in order to provide general codes and themes respectively. Instead of pre-determined codes, they were derived from the data. The questionnaires were checked again and again in order not to miss any significant details, and codes were rearranged each time. Frequencies of codes were tallied on a separate sheet for category formation. Subsequently, summarizing content analysis was adopted in order to reduce the codes in a manageable portion. Finally, the results were summarized, speculative inferences were made and then foci for further research were suggested.

\section{Results}

The data analysis process started with the semi-structured questionnaire consisting of Section A which covers personal details of the participants and Section B describing the concern items and their likely reasons. In the first section properties such as age, gender, academic qualifications, and teaching experience periods were analyzed and tabulated. As can be seen from Table 1, 26, $8 \%$ of the participants were female and $73,2 \%$ of them were male.

Table 1. Gender

\begin{tabular}{lcccc}
\hline & Frequency & Percent & Valid Percent & Cumulative Percent \\
\hline Valid Male & 11 & 26,8 & 26,8 & 26,8 \\
Female & 30 & 73,2 & 73,2 & 100,0 \\
\hline Total & 41 & 100 & 100 & \\
\hline
\end{tabular}

Moreover, Table 2 illustrates that almost half of the participants were between the 26-30 ages and $24 \%$ of them were between $20-25$ ages. Only $9,8 \%$ of the instructors were between $36-50$. Therefore, it could be deduced from the data that the participants of this study were quite young, in other words, they were in the beginning of their teaching career.

Table 2. Age

\begin{tabular}{lccccc}
\hline & & Frequency & Percent & Valid Percent & Cumulative Percent \\
\hline Valid & $20-25$ & 10 & 24,4 & 24,4 & 24,4 \\
& $26-30$ & 19 & 46,3 & 46,3 & 70,7 \\
& $31-35$ & 8 & 19,5 & 19,5 & 90,2 \\
& $36-40$ & 2 & 4,9 & 4,9 & 95,1 \\
& $46-50$ & 2 & 4,9 & 4,9 & 100,0 \\
\hline Total & & 41 & 100,0 & 100,0 & \\
\hline
\end{tabular}


As Table 3 suggests, when the academic qualifications of the participants were investigated, the statistical data shows that $65,9 \%$ had BA degrees while 29,3\% held MA degrees and it was followed with $\mathrm{PhD}$ degree by $4,9 \%$. Hereinbefore, the population of this research was quite young.

Table 3. Academic qualifications

\begin{tabular}{lccccc}
\hline & & Frequency & Percent & Valid Percent & Cumulative Percent \\
\hline Valid & BA & 27 & 65,9 & 65,9 & 65,9 \\
& MA & 12 & 29,3 & 29,3 & 95,1 \\
& PhD & 2 & 4,9 & 4,9 & 100,0 \\
\hline Total & & 41 & 100,0 & 100,0 & \\
\hline
\end{tabular}

As to the teaching experiences, Table 4 demonstrates that $61 \%$ of the participants have been working as an EFL instructor between 0-5 years. The ones working between 6-10 years constituted the $24,4 \%$ of the participators.

Table 4. Teaching experiences (year)

\begin{tabular}{llcccc}
\hline & & Frequency & Percent & Valid Percent & Cumulative \\
\hline Valid & $0-5$ & 25 & 61,0 & 61,0 & 61,0 \\
& $6-10$ & 10 & 24,4 & 24,4 & 85,4 \\
& $11-15$ & 5 & 12,2 & 12,2 & 97,6 \\
& $26-30$ & 1 & 2,4 & 2,4 & 100,0 \\
\hline Total & & 41 & 100,0 & 100,0 & \\
\hline
\end{tabular}

The second part of the analysis deals with the concerns items and their representation on 4-point Likert scale. One of the research questions of the current study was what the academic concerns of EFL instructors working at tertiary level were. With a view to enlighten this issue, the frequencies of the concerns were calculated and the most concerning items were provided by their statistical values.

11 items were given in the questionnaire and participants were asked to choose their concern level from 1 to 4 . Then teachers stated why they felt so concerned by giving justifications as to their concerns. The table given below summarizes the percentages and statistical values of these items' concern on the scale.

One of the research questions of the current study was what the academic concerns of EFL instructors working at tertiary level were. The table given below summarizes the percentages and statistical values of these items' concern on the scale. 
Table 5. Concern items and their statistical values

\begin{tabular}{lllllllc}
\hline Items & \multicolumn{4}{c}{ Scale \%* } & \multicolumn{3}{c}{ Statistics** } \\
\hline & 1 & 2 & 3 & 4 & $\mathrm{M}$ & $\mathrm{SD}$ \\
1. Methodology & 48,8 & 39,0 & 7,3 & 4,9 & 3,32 &, 820 \\
2. Content & 51,2 & 24,4 & 14,6 & 9,8 & 3,17 & 1,022 \\
3. Technology & 24,4 & 39,0 & 24,4 & 12,2 & 2,76 &, 969 \\
4.ProfessionalAccountability & 65,9 & 17,1 & 7,3 & 9,8 & 3,30 &, 997 \\
5. Classroom issues & 53,7 & 31,7 & 7,3 & 7,3 & 3,32 &, 937 \\
6.Learner-related issues & 46,3 & 41,5 & 2,4 & 9,8 & 3,24 &, 916 \\
7. Administrative issues & 19,5 & 41,5 & 26,8 & 12,2 & 2,68 &, 934 \\
8. Testing & 56,1 & 24,4 & 7,3 & 12,2 & 3,24 & 1,044 \\
9. Collegial support & 34,1 & 39,0 & 19,5 & 7,3 & 3,00 &, 922 \\
\hline
\end{tabular}

Table 5 presents that among the 41 respondents' overall mean ratings the highest rate belongs to job satisfaction $(M=3,34)$. Classroom issues follow the job satisfaction very closely. Issues associated with accountability $(M=3,30)$, testing and learner-related issues $(M=3,24)$, school environment $(M=3,20)$, content $(M=3,17)$ and collegial support $\quad(M=3,0)$ were rated on "extremely concerned" and "very concerned" on the scale. The less concerning items compared to other 9 were found to be technological $(\mathrm{M}=2,76)$ and administrative issues $(M=2,68)$. Further analysis of the data showed that women were more significantly concerned about testing (Mann-Whitney $\mathrm{P}=0.002$ ) collegial support (Mann-Whitney $\mathrm{P}=0.058$ ) than their male colleagues.

Furthermore, concern over methodology, technology and testing according to teaching experience, instructors working between 0-5 years; concern over content, administrative issues, collegial support, school environment and job satisfaction for instructors working between 6-10 years, and concern over professional accountability, classroom issues and learner-related issues were higher for instructors working between 11-15 years compared to the other groups.

Although participants were asked to write their comments about the reasons of their concerns for the items given in the questionnaire, not all of them completed these parts 31 of the respondents gave detailed information about their concerns which helped the quantitative data to elucidate qualitatively.

When the comments were investigated, a common tendency was observed: the majority of the participants used concern items and "important" adjective throughout the questionnaire. Therefore, the biggest percentages always went to the concern item itself and important. To the instructors, benefitting from methods, approaches and techniques were quite important since they guide instructors and help them in their teaching; however, there should be some adaptations and factors such as, learners' background and learning styles should be taken into account. Perhaps a quotation from an instructor would explain it better: "They are very 
important for me since they shed lights on the way we teach our students and give ideas how to teach each and every skill. However, the way we integrate the approaches into the classroom should be a bit flexible in case they fail addressing some students whose needs cannot be met completely with the help of these methods". One of the experienced instructors added to that "Is it possible to teach without using any methods? Those who teach without any methods must be genius".

Item regarding technological concerns, it was noted that most of the EFL instructors regard the existence of technology in EFL classes quite normal and many of them commented that they love using technology in their classes. Although instructors were highly sensitive about it, some of the instructors did not regard it sine qua non.

It is interesting to note see that some of the instructors take it something we cannot live without as in this excerpt: "As we live in the 21th century we can't live without technology. They are born with it. Without technology we are useless". On the other hand, some instructors, though quite few, found it not necessary. One of the experienced male teachers expressed his opinions as follows: "The most important thing is the "Teacher", the others are supplementary topics, it is not necessary at all. If you are a good teacher, you can teach without it".

General concerns of teachers are lack of access to internet in classrooms and absence of smart boards. Also, some of them find course hours limited; they just barely cover the content and do not have time for "extra-curricular" activities like letting students do online exercises or show them a video etc.

Speaking of content, it is one of the most concerning issues EFL instructors experience according to their account. Choosing the right book and content were the most pressing concerns of teacher. An instructor expressed it as follows: "More important than the methodology. It is the map of your way. If it is not well-defined, you can never find your way. Also, choosing the course book may sometimes determine the pace of the whole year".

Another instructor commented that they have to follow certain content due to high stake tests; these tests constituted a big proportion of their concerns. A couple of instructors stated that they have to follow the content given by their institution due to the examination system and they feel quite under pressure. One another instructor vocalized as follows: "We use... as the course material. It is a very comprehensive book, but it some parts, especially the listening section are really long and challenging for the students. in terms of the objectives of the curriculum, we do not teach functional language in our program, which makes the target language less internalized by the students". Thus, instructors were mostly concerned about the content which is handed down to them, or does not fit to their learners' needs and interest and they require a serious adaptation.

As professional accountability delved into detail, it is noted that a great number of instructors taking part in this study equated being "professional" with being "updated", well-educated, "trusted". Most of the instructors complained about lack of in-service training facilities, even one of them commented on administration's negative attitude towards attending conferences and seminars, and this shows us that institutional factors are quite effective in the eyes of EFL 
instructors. Another concern was ineffectiveness of trainings; the instructor expressed in this way: "There are some activities and a special unit for teacher development in my school, yet I don't think that it really works well for the teachers. More practical tools and activities should be incorporated into teacher education". Even though trainings are organized at institutions, they should serve their purpose and meet both the needs of learners and teachers. One another concern was the work place conditions. "Professional development depends on personal endeavor in the institution where I work. Work conditions don't contribute to better my teaching skills". Moreover, residence of instructors was of high concern for one of the instructors. "I try to improve my teaching skills by seminars, workshops, but I can't have access to a variety of educational resources because of the place I reside in". We can deduce from their accounts that not only institutions but also the place they reside or work is very pivotal.

One of the most surprising data gathered from data regarding accountability issues was the high self-confidence of an instructor. "Of course it is necessary for teachers to keep themselves updated and improve themselves regarding certain points. However, when I look at myself, I believe I can easily survive in my classrooms in the future without any training". In sum, though the majority of the respondents found these issues concerning and crucial, this instructor believed that s/he could survive without any further training.

Unlike others, classroom-related issues were categorized into two groups: terms and attitudes-feelings. Instructors were extremely concerned about school environment and classroom atmosphere. EFL instructors linked success with discipline, clear-cut rules, positive and friendly classroom ambiance. As one of the instructors expressed: "I believe classroom environment affects the performances and participation a lot. When students feel comfortable in the class, they become more willing to learn." Discipline and classroom management skills were found fundamental in the teaching process by a few instructors. "Classroom atmosphere is the most important for my teaching character. I always have some strict rules and a disciplined atmosphere. Teaching is a work of discipline and I cannot imagine a classroom without them." In order to strengthen the connection between the teachers and learners, our instructor stated that "First of all, it is essential to establish rapport and positive classroom environment to maximize the learning of the students where they do not hesitate to speak. This can be done though necessary and appropriate classroom management techniques."

The responses given to learner-related issues were somewhat similar to the ones given for classroom issues, which was quite understandable since learners are one of the parties in teaching and learning. Motivation was the leader of all the terms and concepts mentioned by the instructors. Their concerns were mainly focused on problems with demotivated learners and how this demotivation factor affected their teaching and morale. One of the instructors stated that "...They are also extremely important since if the learners have preparedness for language learning, the teacher can easily initiate the teaching. However, if they are not motivated enough or if they have social and economic problems, these can be obstacles to make the learners ready for the learning process." As it could be deduced from the excerpt that motivation is seen as a key to successful learning process and we can support these 
statements with comments of another colleague: "Each learner has his/her own style of learning because of individuality, but that is the difficult part as all teachers we have to cope with. If the learner is not ready and s/he doesn't want to "take risks" you have to include him/her into the classroom and problematic students may bully you and the classmates as well."

The actors of the administrative issues could be summarized as teachers, principals or administrators. However, when their role and spheres of influences are taken into consideration, these roles may interchange between leading star and co-star. This gap between the principals and instructors concern them greatly. in reference to their comments, several instructors were worried about their ideas' not being taken into account and the fact that they cannot take part in any decision-making process whatsoever. An instructor summarized the situation like this: "I hear language instructors who feel demotivated because the administration. Sometimes, the administration does not allow teachers to attend seminars and conferences or apply new methods in their classrooms. All the teachers are forced to follow the same book or procedure in their classrooms. However, the teachers should be free to a certain degree as they are the ones who know their students best. Therefore, the administration should be trained about the important issues of language teaching."

The instructor focuses on the importance of collaboration between the teachers and administrative and also points at the necessity of administrators' training to keep up with the latest issues or trends. On the other hand, a few instructors drew attention to not collaboration but to more space and right to be given to them. She expressed her opinions as "They (administrative issues) are not important at all because a teacher knows about the classroom and the issues about students better than the principals do and organize the process of learning accordingly. In addition to this, school policies may not be up-to-date so the teacher should have the authority to make decisions about her / his own classes."

Although testing was the least commented part of the questionnaire, valuable insights were derived from instructors' comments. It was possible to find reliability and validity concepts in almost each comment. EFL instructors were quite concerned how valid or reliable their tests. They were also concerned about backwash effect of tests taken state-wide. Moreover, they emphasized the vitality of right assessment tools and their impact on learning processes.

An instructor commented on this issue as follows: "If we aren't assessing the right things or our tools are not reliable enough we cannot be sure how successful the program is or how much the students gained from it. I think it is very important. There should be specialized staff dealing with the assessment." She seems to believe that there should be extra help regarding assessment from a professional and support the need of a program evaluator to guide instructors and administrators.

Deduced from the data, one of the key factors of being successful and helpful at institutions is collaboration or cooperation. Instructors did not disregard how necessary it is to work in a supportive and friendly environment where you can share your experiences and that increases your job motivation. For this item, perhaps it would be more interesting to give an example 
not from a perspective which favors collegial support but from a point of view that does not regard it so important. "Having good relationship with colleagues may indirectly influence teaching and learning because of its effect on teachers' happiness. However, even if you do not collaborate or have good relationship with them, you can teach in your class." What we can induce from her comments that collaborating with colleagues have impact on teacher's happiness, but if there is not any collaboration, it is not at the end of the world.

Similar to learner-related issues, socio-cultural background of learners and physical conditions of the institutions are fundamentally important. An English instructor complained about the size of the classroom in her comments. "Some classrooms are really small, and also not convenient for language teaching. Teaching a language, we, as teachers prepare lots of kinesthetic activities. So if the class is too small for that, efficiency of teaching and learning decrease." The comments of this instructor approve the concerns of the previous instructor. "These are the important environmental factors affecting the teaching and learning process. Seating arrangement for instance is one of the things I consider a lot. I need to arrange the seating in accordance with the activity type and to increase the interaction among the students."

The physical distance of buildings on a campus might have negative impacts of collegial support and communication between learners and instructors. She commented on this as follows: "However, most state universities don't have very good physical conditions. For example, we have four different buildings in the same campus so it's very difficult to communicate and collaborate with each other."

The final concern is job satisfaction which was highly commented on in this study. Low salaries and long working hours lead concerns with regards to job satisfaction. Apart from few instructors who put the money issue on a subsidiary basis and regarded their best contentment could be measured not with money but with the positive feedback received from his learners, the majority of the English instructors did not find salaries satisfactory and complained about long working hours.

"In terms of salary and workload I feel somewhat satisfied. In terms of professional development, I feel I'm getting worse and worse each day." Another instructor stated that "To motivate our students we need to be motivated. Last summer I taught 35 hours in one week and it was a disaster for me. Generally I am a patient person but in those days I became a different person. Having a good relationship with colleagues is also important because you are at school all day."

To close this section, the last two quotes given above from English instructors summarize the situation in which they all have been through in general. English instructors need improvements in their salaries and working hours. As any other human beings, instructors need to be motivated to become more effective and successful in their work and those factors mentioned above are only the tip of the iceberg. More fathoms should be taken to the deep waters. 


\section{Discussion}

This paper gave an account of what EFL instructors' professional concerns and the reasons for these concerns were. Moreover, the relationship between gender and teaching experience was investigated. English instructors were asked to rate their concern level on a scale from 1 to 4 (1-extremely concerned, 2-very concerned, 3-somewhat concerned, 4-not concerned at all) and then to answer open ended questions after rating each concern item. These analyses showed that job satisfaction, $(M=3,34)$ was most concerning issue for English instructors in their teaching career. Classroom issues, such as classroom management, discipline etc. followed job satisfaction very closely. This result is in line with Griffiths' study (2012) in terms of the vitality of classroom issues on the concern rate. Issues related to accountability $(M=3,30)$, testing and learner-related issues $(M=3,24)$, school environment $(M=3,20)$, content $(M=3,17)$ and collegial support $(M=3,0)$ were rated on "extremely concerned" and "very concerned" on the scale.

The less concerning items compared to other 9 were technological $(M=2,76)$ and administrative issues $(\mathrm{M}=2,68)$. Compared to the EFL instructors in Griffiths' research, the EFL instructors in the current research were less concerned about technology (Griffiths,

2012). For the comparison of female and male professional concerns gender variable and concern items underwent Man-Whitney $U$ Test. According to the results of this test, female EFL instructors were more concerned about issues, such as methodology, content, technology, professional accountability, classroom issues, testing, collegial support, and job satisfaction in contrast to their male peers which is another general result that female EFL teachers are more concerned in contrast to their male colleagues (Pigge \& Marso, 1987; Çetinkaya, 2012 \& Griffiths, 2012). So as to determine the relationship between the teaching experience in terms of year and concern items, chi-square tests were administered. According to the results, for methodological issues, instructors who have worked between 0-5 years were "extremely concerned" than other age groups. As to the content, technology, classroom, learner-related and administrative issues, collegial support, job satisfaction, school environment and testing, the trend follows the same pattern, so to speak, as the teaching experiences of the instructors' increase, the concern levels are inclined to go down. However, as stated by Çetinkaya (2012), the relationship between the teachers' experience and level of concern is not very clear.

Professional accountability and methodology had the highest percentage of concerns among 0-5 year experienced instructors, whereas administrative issues and collegial support had the highest concern level for 6-10 year instructor groups. As for the 11-15 year experienced instructors, the most worrisome issues were linked to classroom and learner-related issues and job satisfaction. In comparison with other experienced groups, instructors having teaching experience between 26-30 years were the most concern-free.

All these results gathered from the data prove that professional concerns of teacher are interrelated and do not follow a stage which comes after the previous one is completed unlike Fuller's stages of concern (1969). For instance, novice instructors (0-5 years) in this study had concerns about task-based issues, self-concerns and impact concerns whether they can affect students' motivation or success in learning. Therefore, it means that teacher can experience three stages of concerns at the same time and these findings accord with earlier 
studies which showed that concerns do not necessarily follow a linear fashion, though it was not the purpose of this study to test it out (Reeves and Kazelskis 1985; Pigge and Marso 1997; Conway, 2001, Watzke, 2007 \& Boz 2008 et.al).

These findings will doubtless be much scrutinized; however, there are at least three main results from this study: Firstly, EFL instructors in this study were very concerned about job satisfaction and classroom issues. Secondly, female teachers were more concerned about almost every item in the questionnaire than their male counterparts. Thirdly, teaching experience did not prove to warrant the alleviation of teacher concerns and also it is not really clear whether these concerns are very much to do with age and teaching experience.

\section{Conclusion}

This study set out to determine professional concerns of EFL instructors in the context of tertiary level in Turkey. The most concerning items were found to be job satisfaction, such as low salary, long working hours etc. and classroom issues like classroom management, discipline and classroom environment etc. On the other hand, technological and administrative issues were the least concerning issues for Turkish EFL instructors. When gender groups compared, it was found out that female instructors were more concerned than their male colleagues in general. The most concerned female group consisted of instructors having been working between $0-5$ years.

The current study might be of interest to pre-service English teachers, practicing English teachers, EFL instructors at universities and teacher educators. Moreover, this research contributes to existing knowledge of EFL instructors' professional concerns by providing more detailed qualitative data gathered from the respondents about the reasons of these concerns. This is one of the few studies carried out in Turkey regarding EFL instructors' professional concerns at tertiary level to the best of researcher's knowledge. However, it is by no means exhaustive because it has its own limitations so does each study have.

One of the biggest drawbacks of this research is the limited number participants reached for the questionnaires. The data collection period collided with the final exam dates at universities; therefore, instructors were quite busy with handling all the stuff at school and their academic works. Thus, a generalization about the professional concerns of EFL instructors both at state and private universities across Turkey cannot be made. Moreover, not all the instructors filling in the questionnaires answered open-ended questions. This experience might show that participant do not really like or want to spend their time on open-ended questions since they will take more time and effort. The last limitation for this study would be the wide scope of areas included as concern items in the questionnaires. In other words, perhaps less items or only one item could be chosen and more detailed and exhaustive data collected from the participant for further studies. For further research, also a larger scale study could be conducted to focus on job satisfaction and classroom issues which are the most concerning items of this study.

Taken together these results and limitations suggest that increasing prominence of personal development, keeping up with latest trends and technology, lack of collaboration between administrative staff and instructors, low salary and long working hours besides inadequacy of 
physical conditions at universities are quite concerning for EFL instructors across Turkey. Taking the learner needs and interests into account is a must for successful and meaningful language teaching and learning; however, instructors' aspirations, needs and concerns should be taken into consideration as well.

Furthermore, professional development activities, such as seminars and workshops should be organized at universities and these events should be encouraged by the administrative staff for the interest of university, instructors and students. Access to internet, technological devices and teaching materials should not be beyond the reach of instructors, and physical conditions of language classes should be designed accordingly.

In a nutshell, just as Griffiths (2012) suggested that instructors are not machines and nor they will be replaced by the machines; teaching is hard-pressed and demanding job, so there should be a clear focus and guideline in order to train and support instructors which has been neglected for a long time. In other words, shifting focus to learner-centred teaching and learning should not create an environment where the instructors are disregarded or left out.

\section{References}

Borg, S. (2003). Teacher cognition in language teaching: A review of research on what language teachers think, know, believe, and do. Language Teaching, 36, 81-19.

Boz, Y. (2008). Turkish student teachers' concerns about teaching. European Journal of Teacher Education, 31(4), 367-377.

Boz, Y. Boz, N. (2010). The nature of the relationship between teaching concerns and sense $\quad$ of efficacy. European Journal of Teacher Education, 33(3), 279-291.

Cohen, L., Manion, L. \& Morrison, K. (2007). Research Methods in Education. E-library: Taylor \& Francis.

Coladarci, T. (1992). Teachers' Sense of Efficacy and Commitment to Teaching. The Journal of Experimental Education, 60(4), 323-337.

Conway, P. F. (2001). Anticipatory reflection while learning to teach: from a temporally truncated to a temporally distributed model of reflection in teacher education. Teaching and Teacher Education, 17, 89-106. http://dx.doi.org/10.14221/ajte.2013v38n5.5

Conway, F. P. \& Clark, M.C. (2003). The journey inward and outward: a re-examination of Fuller's concerns-based model of teacher development Teaching and Teacher Education, 19, 465-482.

Çelik, S., Bayraktar-Çepni, S. \& İlyas, H. (2012). The need for ongoing professional development: Perspectives of Turkish university-level EFL instructors. Procedia - Social and Behavioral Sciences 70, 1860 - 1871.

Çetinkaya, B. (2012). Understanding Teachers in the Midst of Reform: Teachers' Concerns about Reformed Sixth Grade Mathematics Curriculum in Turkey. Eurasia Journal of Mathematics, Science \& Technology Education, 8(3), 155-166. 
Durmuş, B., Yurtkoru, E. S. \& Çino, M. (2011). Sosyal Bilimlerde SPSS'le Veri Analizi. (4 $^{\text {th }}$ ed.). Istanbul: Beta.

Freeman, D. (1989). Teacher Training, Development, and Decision Making: A Model of Teaching and Related Strategies for Language Teacher Education. TESOL Quarterly, 23(1), $28-46$.

Fuller, F. (1969). Concerns of teachers: A developmental conceptualization. American Educational Research Journal, 6, 207-226.

Ghaith, G., \& Shaaban, K. (1999). The relationship between perceptions of teaching concerns, teacher efficacy, and selected teacher characteristics. Teaching and Teacher Education, 15, 487-496.

Griffths, C. (2012). Focus on the teacher. ELT Journal, 66 (4), 468-476.

Hagger, H. \& Malmberg, L. E. (2011). Pre-service teachers' goals and future-time extension, concerns, and well-being. Teaching and Teacher Education, 27, 598-618.

Halloway, K. (2003). A Measure of Concern: Research-based program aids innovation by addressing teacher concerns. Retrieved from

http://learningforward.org/docs/tools-for-learning-schools/tools2-03.pdf?sfvrsn=2

Hord, S. M., \& Hall, G. E. (2000). Implementing change: Patterns, principles, and potholes. New York: Allyn and Bacon.

Hürsen, Ç. (2011). Determine the attitudes of teachers towards professional development activities. Procedia Technology, 1, 420-425.

İyidoğan, F. (2011). Personal Factors Affecting Experienced English Teachers' Decisions Whether Or Not to Engage In Professional Development Activities. Retrieved from http://www.thesis.bilkent.edu.tr/0005037.pdf

Kim, H. \& Cho ,Y. (2013). Pre-service teachers' motivation, sense of teaching efficacy, and expectation of reality shock. Asia-Pacific Journal of Teacher Education, 1-15. http://dx.doi.org/10.1080/1359866X.2013.855999

Kleinsasser, R.C. (2013). Language Teachers: Research and studies in language(s) education, teaching, and learning in Teaching and Teacher Education, 1985-2012. Teaching and Teacher Education, 29, 86-96. http://dx.doi.org/10.1016/j.tate.2012.08.011

Kwok, P.W. (2014). The role of context in teachers' concerns about the implementation of an innovative curriculum. Teaching and Teacher Education, 38, 44-55.

Liu, Y \& Huang, C. (2005). Concerns of teachers about technology integration in the USA. European Journal of Teacher Education, 28(1), 35-47.

Öztürk, G. (2013). Job Burnout Experienced by Turkish Instructors of English Working at State Universities. International Online Journal of Educational Sciences, 5 (3), 587-597.

Pigge, F. L., \& Marso, R. N. (1997). A seven year longitudinal multi-factor assessment of teaching concerns development through preparation and early teaching. Teaching and Teacher Education, 13, 225-235. 
Poulou, M. (2007). Student - teachers' concerns about teaching practice. European Journal of Teacher Education, 30(1), 91-110. http://dx.doi.org/10.1080/02619760600944993

Reeves, C. K., \& Kazelskis, R. (1985). Concerns of preservice and inservice teachers. Journal of Educational Research, 78(5), 267-271.

Roofe, C. G., \& Miller, P. (2013). "Miss, I Am Not Being Fully Prepared": Student Teachers' Concerns About Their Preparation at a Teacher Training Institution in Jamaica. Australian Journal of Teacher Education, 38(5), 1-13.

http://dx.doi.org/10.14221/ajte.2013v38n5.5

Veenman, S.(1984). Perceived Problems of Beginning Teachers. Review of Educational Research Summer, 54 (2), 143-178.

Younger, M., Brindley, S., Pedder, D., \& Hagger, H. (2004). Starting points: Student teachers' reasons for becoming teaching and their preconceptions of what this will mean. European Journal of Teacher Education, 27, 245-264.

Watzke, J. L. (2007). Longitudinal research on beginning teacher development: Complexity as a challenge to concerns-based stage theory. Teaching and Teacher Education, 23, 106-122.

Woodcock, S., Hemmings, B., \& Kay, R. (2012). Does Study of an Inclusive Education Subject Influence Pre-Service teachers' Concerns and Self-Efficacy about Inclusion?. Australian Journal of Teacher Education, 37(6), 1-11.

http://dx.doi.org/10.14221/ajte.2012v37n6.5

Wyant, D. (2010). APA Quick Reference Guide. University of North Carolina School of Social Work.

Zacharias, N. T. (2003). A survey of tertiary teachers' beliefs about English Language Teaching in Indonesia with regard to the role of English as a global language. Retrieved from http://asian-efl-journal.com/thesis_N_Zacharias.pdf.

\section{Appendix}

\section{Teacher Concerns Questionnaire}

Dear participant,

The aim of this study is to reveal the professional concerns of English instructors working at Turkish universities. Please answer each question given below. Your responses and demographic information will remain anonymous and they will be used for this research only. Thanks for your cooperation.

Inst. Esra Yatağanbaba

Hitit University 


\section{SECTION A}

This section of the questionnaire refers to background or demographic information. Your responses will remain anonymous. Please tick $(\sqrt{ })$ the item which is appropriate for you. Your cooperation is really appreciated.

Concerning your own background, please fill in the following:

1. Sex:

Male

Female

2. Age:

20-25

41-45

26-30

46-50

31-35

3. Highest academic qualifications.
Bachelor's degree
Doctorate degree
Master's degree
Other; please specify

4. Number of years of teaching experience:
$0-5$
16-20
6-10
$21-25$
11-15
26-30

\section{SECTION B}

This section aims to reveal the main concerns of EFL instructors at universities in regard to their approaches towards Methodology, Content, Technology, Professional accountability, Classroom issues, Learner Related Issues, Administrative Issues, Testing, Collegial support, School Environment and Job Satisfaction. Thanks for your cooperation. 
Please indicate your answer by choosing from $\underline{\mathbf{1} \text { to } \mathbf{4}}$ for the following items. And please explain why these topics are concerning for you.

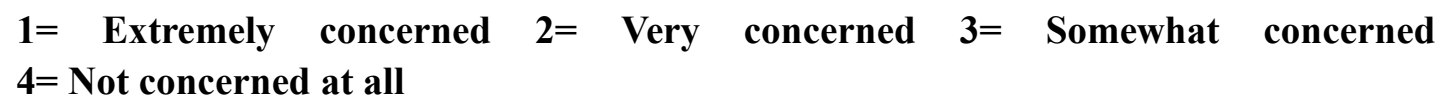

Methodology

$\begin{array}{llll}1 & 2 & 3 & 4\end{array}$

(Language teaching and learning methods and approaches)

Please explain your reasons under each item.

Content

$\begin{array}{llll}1 & 2 & 3 & 4\end{array}$

(Curriculum, content of the book etc.)

Please explain your reasons under each item.

Technology

$\begin{array}{llll}1 & 2 & 3 & 4\end{array}$

(Smart boards, use of computers, internet etc.)

Please explain your reasons under each item.

Professional Accountability

$\begin{array}{llll}1 & 2 & 3 & 4\end{array}$

(Professional Development, Teacher Education)

Please explain your reasons under each item.

Classroom Issues

$\begin{array}{llll}1 & 2 & 3 & 4\end{array}$

(Classroom management, discipline issues, classroom environment etc.)

Please explain your reasons under each item.

\section{Learner-related Issues}

(Motivation, learner preparedness, socio-economic issues etc.)

Please explain your reasons under each item.

$\begin{array}{lllll}1 & 2 & 3 & 4\end{array}$


Administrative Issues

(Relationship with principals, school policies etc.)

Please explain your reasons under each item.

\section{Testing}

$\begin{array}{llll}1 & 2 & 3 & 4\end{array}$

(Reliability and validity of assessment tools etc.)

Please explain your reasons under each item.

$\begin{array}{llll}1 & 2 & 3 & 4\end{array}$

\section{Collegial Support}

$\begin{array}{llll}1 & 2 & 3 & 4\end{array}$

(Relationship with colleagues, collaboration etc.)

Please explain your reasons under each item.

\section{School environment}

$\begin{array}{llll}1 & 2 & 3 & 4\end{array}$

(Physical conditions, students' educational and cultural background etc.)

Please explain your reasons under each item.

$\underline{\text { Job Satisfaction }}$

$\begin{array}{llll}1 & 2 & 3 & 4\end{array}$

(Salary, workload etc.)

Please explain your reasons under each item.

\section{THANK YOU FOR YOUR CONTRIBUTIONS}

\section{Copyright Disclaimer}

Copyright for this article is retained by the author(s), with first publication rights granted to the journal.

This is an open-access article distributed under the terms and conditions of the Creative Commons Attribution license (http://creativecommons.org/licenses/by/3.0/). 